\title{
Deneyim Kalitesinin Memnuniyet ve Yaşam Kalitesine Etkisi: Kırıkkale Büyük Şehir Parkında Bir Uygulama*
}

\section{The Effect of Experience Quality on Satisfaction and Quality of Life: An Application in Kırıkkale Big City Park}

\author{
Dr. Öğr. Üyesi Ali SOLUNOĞLU \\ Kırıkkale Üniversitesi \\ Turizm Fakültesi \\ E-posta: alisolunoglu@msn.com
}

Dr. Öğr. Üyesi Özgür YAYLA

Akdeniz Üniversitesi

Manavgat Turizm Fakültesi

E-posta: ozguryayla@akdeniz.edu.tr

\section{Öz}

Teknolojik ve endüstriyel gelişim içerisinde olan kent yaşamında, kırsal yaşantının dinlendirici, güç verici görüntüsü ve ortamı kaybolmaktadır. Bu durum zamanla kişilerin yaşam kalitesini olumsuz etkilemiş ve yerel yönetimleri rekreasyon faaliyetlerini özendirecek alanlar geliştirmeye yöneltmiştir. Yerel yönetimler bağlamında bunun en iyi örnekleri park ve bahçelerdir. Özellikle Türkiye'de "Millet Bahçeleri" kavramının yer almaya başlamasıyla bu tür park ve bahçelerin halkın refahı anlamında yaşam kalitesine nasıl bir katkı sunduğunun bilimsel olarak ortaya konulma intiyacı ortaya çıkmıştır. Bu amaçla Kırıkkale ilinde yüz yüze anket tekniği ile 460 katılımcıdan veriler elde edilmiştir. Toplanan veriler ilgili istatistik programı yardımıyla yüzde, frekans ve ortalama gibi tanımlayıcı istatistiklerin yanı sıra farklılık ve ilişki test analizlerine de tabi tutulmuştur. Analizler sonucunda park ve bahçeleri ayda 2-3 defa sıklıkta ziyaret edenlerin deneyim kalitesi, memnuniyet ve yaşam kalitesi algısı arasında pozitif yönlü ve istatistiksel açıdan anlamlı sonuçlar elde edilmiştir.

Anahtar Kelimeler: Turizm, Millet Bahçeleri, Yaşam Kalitesi, Rekreasyon, Deneyim kalitesi.

\begin{abstract}
The relaxing, empowering image and environment of rural life is lost in the city life which is in technological and industrial development. Through time, this situation had adversely affected the quality of life of individuals and led the local governments to develop areas to encourage recreational activities. The best examples of this case within the context of local governments are parks and gardens. Especially in Turkey with the introduction of "Public Gardens" concept the need to scientifically demonstrate how such parks and gardens contribute to the quality of life in terms of public welfare has become an important aspect. For this purpose, the data were obtained from 460 participants by face to face survey technique in Kırıkkale province. The collected data were analyzed through descriptive statistics such as percentage, frequency and mean as well as difference and correlated test analyzes with the help of the related statistical program. As a result of the analysis, positive and statistically significant results were obtained between the experience quality, satisfaction and life quality perception of those who visit the parks and gardens 2-3 times a month.
\end{abstract}

Key Words: Tourism, Public Gardens, Quality of Life, Recreation, Quality of Experience 


\section{Giriş}

Yaşam kalitesi, kelime anlamının da çağrıştırdığı gibi, bireyin yaşamına ilişkin niteliklerin, yaşadığı çevrenin farklı boyutlarının (fiziksel, sosyal çevre, kültür vb.) kendi deneyimleri ve algısı doğrultusunda değerlendirilmesi sonucunda varılan kişisel yargıdır. Insan yaşamı ile ilgili olan yaşam kalitesi kavramı, konuyu farklı yönleriyle ele alan çok sayıda araştırmacının uzlaştığı üzere, çok boyutlu bir kavram ve disiplinler arası bir sorgulama alanıdır (Szalai, 1980, Diener ve Suh, 1997, Van Kamp ve diğ., 2003, Veenhoven 2007).

Farklı bileşenlerin ortaklaşa geliştirdiği bir çıktı olarak adlandırılabilecek olan yaşam kalitesinin söz konusu niteliği, literatürde farklı boyutlarla ilişkili özelleşmiş tanımların ve ölçümlerin geliştirilmesini beraberinde getirmiştir. Yaşam kalitesi; esenlik, refah düzeyi ve yaşam tatmini kavramları ile ilişkili olup, bireyin kendi yaşamının yanı sıra, gündelik hayatını sürdürdüğü çevreye ilişkin algısına odaklanma yoluyla, çevre eksenli yaşam kalitesi ortaya çıkmaktadır. Yaşam kalitesi bireylerin hayat içerisindeki durumlarını, beklentileri, hedefleri, hayat standartları, ait oldukları kültürel yapı ve değerler sistemi çerçevesinde algılama ve değerlendirme biçimidir (WHO, 1995). Bu değerlendirme bireyin fiziksel, psikolojik ve demografik niteliklerini kapsayan kişisel özellikler, sosyal ilişkiler, ekonomik durum ve sağlık durumunu ifade etmektedir. Bunun yanında, gündelik yaşamın sürdürüldüğü çevreye göre biçimlenmekte olup, yaşamın farklı bölümlerinde içinde bulunulan zaman dilimine, dönemin koşullarına ve bu kapsamda oluşan öznel algıya bağlı olarak değişiklik göstermektedir (Sato ve diğ., 2017; Spiers ve Walker, 2009). Bu çerçevede yaşam koşullarının önemli bir kısmını gündelik yaşam çevresi oluşturmakta olup, mimari olarak müdahale edilebilir olan boyutlar, çevrenin nesnel koşullarını biçimlendirmektedir. Bu koşullar, bireyin öznel algısı doğrultusunda çevreyi deneyimlemesi ile elde ettiği deneyim kalitesi, memnuniyet ve yaşam kalitesini oluşturmaktadır (Wu ve diğ., 2018).

"Deneyim Kalitesinin Memnuniyet ve Yaşam Kalitesine Etkisi; Kırıkkale Büyük Şehir Parkında Bir Uygulama" isimli bu çalışmanın amacı halkın memnuniyet düzeyini etkilediği düşünülen park ve bahçelerin yaşam kalitesine etkisinin ortaya konulmasıdır. Buna bağlı olarak yerel yönetimlerin gelecekte yapacakları stratejik eylem ve planların belirlenmesine ve turizm ile pazarlama alanyazınında çalışan akademisyenlere katkı sağlaması amaçlanmaktadır.

\section{Kavramsal Çerçeve}

Kovacs'a (2007) göre memnuniyet kavramı, bireylerin algıları ile beklentileri arasında oluşan fark ile alakalıdır, farkın azlığı ya da çokluğu memnuniyet düzeyini belirlemektedir. Fark az ise memnuniyet yüksek olacakken farkın fazla olduğu durumlarda memnuniyet düzeyleri düşük olmaktadır. Oliver (1993) ise memnuniyet kavramını, "var olan hizmet olayına gösterilen bilişsel ve hissedilen tepki' olarak tanımlamaktadır. Boş zaman ve memnuniyet ilişkisini inceleyen Beard ve Ragheb (1980) ise boş zaman memnuniyeti kavramını "bireyin gerçekleştirdiği olumlu algı veya duygular boş zaman etkinlikleri ve seçimleriyle ilgili olmanın sonucu olarak meydana gelir" şeklinde tanımlamışlardır. Bir başka ifadeyle boş zaman memnuniyeti kişilerin boş zaman faaliyetleri sürecindeki hoşnutluk ölçüsüdür. Boş zaman memnuniyeti hakkında birden fazla tanımlama yapılmaktadır. Boş zamanı değerlendirmedeki memnuniyet duygusu yapılan en yaygın tanımlamadır. Boş zaman memnuniyeti katılım odaklı tanımlarda bireyin ne yaptığı önemli iken; deneyim odaklı boş zaman memnuniyeti tanımında ise hissedilen durum ve deneyimler önem arz etmektedir. Memnuniyet duygusunda tecrübeler, farklılıklar, bireyin durumdan bekledikleri, arzu ettikleri ve davranışı arasındaki farklılıklara dayanmaktadır. Francken ve van Raaij (1981) boş 
zaman etkinliklerindeki istenilen ve gerçekleştirilen durum arasında var olan memnuniyet farklılığını araştırmış ve incelemişlerdir. Çalışmaları sonucunda elde edilen verilerde iyimser bakış açısına sahip olup yaşları ileri olan bireylerin yüksek derecede boş zaman memnuniyetine ulaştıkları; genç yaştaki kötümser hale sahip bireylerin düşük boş zaman memnuniyet duygusuna sahip oldukları görülmüştür. Lu ve Hu'nun (2005) çalışmaları incelendiğinde bireylerin boş zaman faaliyetlerinden farklı düzeyde memnuniyet ve yarar sağladığı belirtilmiştir. Boş zaman etkinliklerinin ciddi yapılan bir faaliyetle gerçekleştirildiğinde kişilerin stres boyutunun arttığı gözlemlenirken akıcılık ve mücadeleciliği tetiklemesi açısından bu tarz etkinliklerle boş zaman memnuniyeti gerçekleştiren bireylerde memnuniyet duygusunun arttığını gözlemlemişlerdir. Ciddi olmayan televizyon izleme vb. gibi boş zaman etkinliğinden elde edilen yarar ve memnuniyet duygusunun ise az olduğunu belirtmişlerdir. Çünkü televizyon izleyen kişilerde sıkılganlık duygusu artmakta olup buna bağlı olarak boş zaman memnuniyet seviyesi düşmektedir. Kişilerin hayat kalitesinde, psikolojik sağlığı, fiziksel sağlığı ve mutlu olma durumunda önemli bir şart olan boş zaman faaliyetlerinden kazanılan memnuniyeti ele almış bilimsel çalışmaların ulusal literatürde az olduğu görülmektedir.

Literatür incelendiğinde Yılmaz ve diğ. (2006) Antalya'da yürüttükleri çalışmada bireylerin rekreasyonel alanlardan memnuniyet düzeylerinin orta seviyede olduğu ve maddi imkânların rekreasyonel faaliyetlere katılmayı etkilediği görülmektedir.

Göktaş (2007) tarafından yürütülen çalışmada boş zaman değerlendirmenin iş yerindeki performansı arttırmaya katkı sağladığı tespit edilmiştir. Yayla ve Çetiner (2019) boş zaman memnuniyetini psikolojik, sosyal ve fiziksel memnuniyet olmak üzere üç grupta incelemişlerdir. Bunun yanı sıra boş zamanlarda gerçekleştirilen faaliyetlerin sağlamış olduğu memnuniyet duygusu yaşam tatminini doğrudan etkilemektedir. Yaşam tatminine bağlı olarak yaşam kalitesi de pozitif yönde değişmektedir.

Araştırma değişkenlerinden bir diğeri olan deneyim kalitesi bireyin yaşam şartları içerisinde ulaşılabileceği kişisel hazzı etkileyen ruhsal, fiziksel ve toplumsal etki olarak ifade edilebilir. Deneyim kalitesini etkileyen birçok faktör bulunmaktadır. Bireysel özellikler, sosyal değişkenler, ekonomik değişkenler, çevresel değişkenler bunlara örnek olarak gösterilmektedir. Yerel yönetimlerin, rekreasyonel alanlarının hazırlanması, geliştirilmesi ve eksikliklerin giderilmesi için göstereceği çaba yöre halkına psikolojik ve sosyal açıdan fayda sağlayacaktır (Yıldız ve diğ., 2016). Bu bağlamda elde edilen sonuçların bilhassa örneklemin seçildiği ilde faaliyet gösteren işletme ve yerel yönetimlere ışık tutacağı düşünülmektedir. Çalışmanın amacı doğrultusunda aşağıda yer alan hipotezler sınanmak üzere geliştirilmiştir.

H1: Rekreasyon alanlarından elde edilen deneyim kalitesi algısı ziyaret sıklığına göre farklılık göstermektedir.

H2: Rekreasyon alanlarından elde edilen memnuniyet ziyaret sıklığına göre farklılık göstermektedir.

H3: Rekreasyon alanlarından elde edilen yaşam kalitesi ziyaret sıklığına göre farklılık göstermektedir.

H4: Rekreasyon alanlarındaki deneyim kalitesi algısının yaşam kalitesi üzerinde pozitif yönde etkisi vardır.

H5: Rekreasyon alanlarındaki deneyim kalitesi algısının memnuniyet üzerinde pozitif yönde etkisi vardır. 
H6: Rekreasyon alanlarındaki memnuniyet algısının yaşam kalitesi üzerinde pozitif yönde etkisi vardır.

\section{Yöntem}

Çalışmada veri toplama aracı olarak anket formu kullanılmıştır. Anket formu iki bölümden oluşmaktadır. İlk bölümde katılımcıların demografik özelliklerini (yaş, cinsiyet, gelir, eğitim düzeyi, medeni durumu) belirlemeye ilişkin sorular yer alırken, ikinci bölümde ise rekreasyon alanlarına yönelik olarak Wu ve diğ. (2018) çalışmasında yer alan 8 ifadeli Deneyim kalitesi ölçeği, Kim ve diğ. (2015) ile Woo ve diğ. (2018) 4 ifadeden oluşan Memnuniyet ölçeği, Woo ve diğ. (2018) 8 ifadeden oluşan Yaşam kalitesi ölçeği kullanılmıştır. Ölçeğe ilişkin tüm ifadeler beşli Likert tipi ölçek (1=Hiç Katılmıyorum, $5=$ Tamamen Katılıyorum) kullanılarak derecelendirilmiştir. Araştırma evrenine ilişkin net bir sayı bulunmadığı için bu araştırmada Kırıkkale ilinin toplam nüfusu evren olarak kabul edilmiştir. 2019 yılı verilerine göre Kırıkkale'nin toplam nüfusu 280.969 olarak tespit edilmiştir (TUIK, 2019). Araştırma örneklemi seçilirken olasılıklı olmayan örnekleme yöntemlerinden kolay ulaşılabilir örnekleme yöntemi kullanılmıştır (Zikmund, 2003). Kolay ulaşılabilir örnekleme yöntemi, yakın çevrede bulunan ve ulaşılması kolayca mümkün olan katıımcıların örnekleme dâhil edilmesidir (Erkuş, 2013: 122). Çalışmanın uygulanabilmesi için gerekli olan etik kurul izni alınmış (Bu çalışmanın Kırıkkale Üniversitesi Sosyal ve Beşeri Bilimler Araştırmaları Etik Kurulu Yönergesinde belirtilmiş Etik ilkelere uygun olduğuna karar verilmiştir. Karar tarih:12.06.2019 Karar Numara: 5) ve Nisan-Haziran 2019 tarihlerinde Kırıkkale Büyük Şehir Parkı ziyaretçilerine yüz yüze anket tekniği uygulanarak elde edilen verilerin niteliğine uygun olarak SPSS paket programı aracılığıyla bulgular analiz edilmiştir. Bu amaçla 460 anketten elde edilen veriler ilgili istatistik programına kodlanarak girilmiştir.

\section{Bulgular ve Tartışma}

Araştırma verilerinden elde edilen bulgular doğrultusunda katılımcıların demografik özellikleri Tablo 1'de gösterilmiştir.

Tablo 1: Katılımcılara İlişkin Demografik Veriler

\begin{tabular}{|c|c|c|c|}
\hline & Demografik Değişkenler & $\mathbf{n}$ & $\%$ \\
\hline \multirow{2}{*}{ Cinsiyet } & Kadın & 203 & 44,1 \\
\hline & Erkek & 257 & 55,9 \\
\hline \multirow{5}{*}{ Yaş } & $18-24$ & 92 & 20,0 \\
\hline & $25-34$ & 113 & 24,6 \\
\hline & $35-44$ & 66 & 14,3 \\
\hline & $45-54$ & 136 & 29,6 \\
\hline & 55 yaş ve üstü & 53 & 11,5 \\
\hline \multirow{4}{*}{ Ziyaret Sıklığı } & Çok Nadir & 12 & 2,6 \\
\hline & Ayda 1 & 15 & 3,3 \\
\hline & Ayda 2-3 & 179 & 38,9 \\
\hline & Haftada 1 & 254 & 55,2 \\
\hline \multirow{2}{*}{ Medeni Durum } & Evli & 234 & 50,9 \\
\hline & Bekâr & 226 & 49,1 \\
\hline \multirow{6}{*}{ Eğitim Durumu } & Okuryazar & 43 & 9,3 \\
\hline & İlköğretim & 116 & 25,2 \\
\hline & Lise & 186 & 40,4 \\
\hline & Ön lisans & 53 & 11,5 \\
\hline & Lisans & 50 & 10,9 \\
\hline & Lisansüstü & 12 & 2,6 \\
\hline
\end{tabular}


Tablo 1'in devamı

\begin{tabular}{|c|c|c|c|}
\hline \multirow{5}{*}{ Kişisel Gelir } & 0-2020も & 100 & 21,7 \\
\hline & 2021-3500も & 260 & 56,5 \\
\hline & 3501-5000も & 62 & 13,5 \\
\hline & 5001-6500も & 25 & 5,4 \\
\hline & 6501 も - ve daha fazla & 13 & 2,8 \\
\hline \multirow{5}{*}{ Meslek } & Kamu Personeli & 154 & 33,5 \\
\hline & Özel Sektör Çalışanı & 135 & 29,3 \\
\hline & Serbest Meslek & 82 & 17,8 \\
\hline & Diğer (Emekli vb.) & 89 & 19,3 \\
\hline & TOPLAM & 460 & $\% 100$ \\
\hline
\end{tabular}

Tablo 1 incelendiğinde araştırma katılımcılarının \%55,9'unun erkek, \%29,6'inin 45-54 yaş aralığında olduğu, \%50,9'unun evli olduğu, \%40,4'ünün lise eğitimine sahip olduğu ve aylık gelirleri incelendiğinde, \%56,5'inin 2021-3500 Türk lirası gelire sahip olduğu, \%33,5'inin kamu personeli olduğu görülmektedir. Ayrıca araştırma anketini cevaplayan katılımcıların \%55,2'sinin ayda 2-3 defa parkları ziyaret ettiğini ifade etmektedir.

Hipotez testleri analizlerine başlamadan önce ölçeklere ilişkin ortalama, standart sapma ve güvenirlik değerlerine aşağıdaki tablolarda yer verilmiştir.

\section{Tablo 2: Deneyim Kalitesi Ölçeğine İlişkin Ortalama, Standart Sapma ve Güvenirlik Değerleri}

\begin{tabular}{|c|c|c|c|}
\hline İfadeler & Ort. & S.S. & $\alpha$ \\
\hline Bu rekreasyon alanının fiziksel çevresi dört dörtlüktür. & 2,00 & 1,379 & \multirow{8}{*}{,799 } \\
\hline $\begin{array}{l}\text { Bu rekreasyon alanındaki fiziksel çevre yüksek } \\
\text { standartlardadır. }\end{array}$ & 2,46 & 1,488 & \\
\hline $\begin{array}{l}\text { Rekreasyon alanında var olan işletmelerin, } \\
\text { katılımcılara fayda sağladıklarını düşünüyorum. }\end{array}$ & 3,32 & 1,245 & \\
\hline $\begin{array}{l}\text { Her zaman, bu rekreasyon alanını ziyaret ettiğimde } \\
\text { eşsiz bir deneyime sahip oluyorum. }\end{array}$ & 2,52 & 1,434 & \\
\hline $\begin{array}{l}\text { Rekreasyon alanına herhangi bir ulaşım sorunu } \\
\text { yoktur. }\end{array}$ & 3,27 & 1,329 & \\
\hline Rekreasyon alanı merkezi bir noktadadır. & 3,28 & 1,414 & \\
\hline $\begin{array}{l}\text { Bu rekreasyon alanının nitelikleri diğer illerde bulunan } \\
\text { rekreasyon alanlarına nazaran üstün bir seviyededir. }\end{array}$ & 3,46 & 1,308 & \\
\hline $\begin{array}{l}\text { Bu rekreasyon alanını ziyaret benim için güzel bir } \\
\text { deneyimdir. }\end{array}$ & 2,94 & 1,552 & \\
\hline
\end{tabular}

Rekreasyon alanlarındaki deneyim kalitesi algısına ilişkin yöneltilen 8 ifadelik ölçeğin ortalama, standart sapma ve güvenirlik değerleri Tablo 2'de gösterilmiştir. Ölçeğin Cronbach's Alpha değeri ,799 olarak yüksek düzeyde güvenirlik sağladığı tespit edilmiştir. Ifadelerin ortalamaları değerlendirildiğinde katılımcıların en fazla olumlu görüş bildirdiği ifade "Bu rekreasyon alanının nitelikleri diğer illerde bulunan rekreasyon alanlarına nazaran üstün bir seviyededir." ifadesi olurken (İfade ort: 3,46), en düşük ortalamaya sahip ifade ise "Bu rekreasyon alanının fiziksel çevresi dört dörtlüktür." (İfade ort:2,00) ifadesi olmuştur.

Tablo 3'te Memnuniyet ölçeğine ilişkin ortalama, standart sapma ve güvenirlik değerlerine yer verilmiştir. 


\section{Tablo 3: Memnuniyet Ölçeğine İlişkin Ortalama, Standart Sapma ve} Güvenirlik Değerleri

\begin{tabular}{|c|c|c|c|}
\hline İfadeler & Ort. & S.S. & $\alpha$ \\
\hline $\begin{array}{l}\text { Rekreasyon alanı ücretsiz olmasına rağmen benim } \\
\text { ihtiyacımı karşıladı. }\end{array}$ & 2,50 & 1,402 & \multirow{4}{*}{,787 } \\
\hline $\begin{array}{l}\text { Genel olarak bu rekreasyon alanını ziyaret için zaman, } \\
\text { para ve çaba harcamak için değer. }\end{array}$ & 3,33 & 1,346 & \\
\hline $\begin{array}{l}\text { Bu rekreasyon alanını ziyaret sonucunda edindiğim } \\
\text { deneyimden memnunum. }\end{array}$ & 3,17 & 1,471 & \\
\hline $\begin{array}{l}\text { Bu rekreasyon alanını ziyaret etmeye karar verdiğim } \\
\text { için mutluyum. }\end{array}$ & 3,21 & 1,365 & \\
\hline
\end{tabular}

Rekreasyon alanlarındaki memnuniyete ilişkin yöneltilen 4 ifadelik ölçeğin ortalama, standart sapma ve Cronbach's Alpha değerleri Tablo 3'te gösterilmiştir. Ölçeğin Cronbach's Alpha değeri ,787 olarak tespit edilmiştir. İfadelerin ortalamaları değerlendirildiğinde katılımcıların en fazla olumlu görüş bildirdiği ifade "Genel olarak bu rekreasyon alanını ziyaret için zaman, para ve çaba harcamak için değer" ifadesi olmuştur (Iffade ort: 3,33). Bunu sırasıyla "Bu rekreasyon alanını ziyaret etmeye karar verdiğim için mutluyum" (Ifade ort: 3,21) ve "Bu rekreasyon alanını ziyaret sonucunda edindiğim deneyimden memnunum" ifadeleri izlemektedir (Iffade ort: 3,17). Bu ölçeğe ilişkin en düşük ortalamaya sahip ifade ise "Rekreasyon alanı ücretsiz olmasına rağmen benim intiyacımı karşıladı" ifadesi olmuştur (İfade ort: 2,50).

Aşağıda yer alan Tablo 4'te 8 ifadeden oluşan Yaşam Kalitesi ölçeğine ilişkin ortalama, standart sapma ve güvenirlik değerlerine yer verilmiştir.

\section{Tablo 4: Yaşam Kalitesi Ölçeğine İlişkin Ortalama, Standart Sapma ve Güvenirlik Değerleri}

\begin{tabular}{|c|c|c|c|}
\hline Ifadeler & Ort. & S.S. & $\alpha$ \\
\hline $\begin{array}{l}\text { Bu rekreasyon alanını ziyaret ettiğim için gerçekten } \\
\text { zevk aldım. }\end{array}$ & 2,62 & 1,227 & \multirow{7}{*}{,829 } \\
\hline $\begin{array}{l}\text { Rekreasyon alanında sunulan hizmetler, genel } \\
\text { anlamda tatmin ediciydi. }\end{array}$ & 2,23 & 1,544 & \\
\hline $\begin{array}{l}\text { Genel olarak, bu rekreasyon alanını ziyaret ettikten } \\
\text { sonra kendimi enerji dolu hissettim. }\end{array}$ & 3,37 & 1,243 & \\
\hline $\begin{array}{l}\text { Rekreasyon alanını ziyaret ettikten kısa bir süre sonra } \\
\text { yaşam tatminimde artış oldu. }\end{array}$ & 2,20 & 1,456 & \\
\hline Şimdiye kadar hayatta istediğim önemli şeyleri aldım. & 3,33 & 1,353 & \\
\hline $\begin{array}{l}\text { Her ne kadar hayatta sıkıntılarım olsa da, rekreasyon } \\
\text { alanını ziyaret ettikten kısa bir süre sonra hayatım } \\
\text { hakkında iyi hissettim. }\end{array}$ & 3,03 & 1,471 & \\
\hline $\begin{array}{l}\text { Genel olarak bu rekreasyon alanındaki deneyimim, } \\
\text { yaşam kalitemi zenginleştirdi ve unutulmaz oldu. }\end{array}$ & 3,25 & 1,347 & \\
\hline $\begin{array}{l}\text { Rekreasyon alanını ziyaretten sonra anlamlı ve tatmin } \\
\text { edici bir hayat sürügümü hissettim. }\end{array}$ & 2,53 & 1,621 & \\
\hline
\end{tabular}

Tablo 4 incelendiğinde Yaşam Kalitesi ölçeğine ilişkin ortalama, standart sapma ve Cronbach's Alpha değerleri görülmektedir. Yaşam Kalitesi ölçeğinde yer alan ifadelerin güvenirlik değeri ,829 olarak tespit edilmiştir. Tüm ölçeklerin Cronbach Alpha değerleri 0,70 'den büyük olması sebebiyle ölçeğin güvenilir olduğu söylenebilir (Büyüköztürk, 2006). Ayrıca ifade ortalamaları değerlendirildiğinde katılımcıların en fazla olumlu görüş bildirdiği ifadenin "Genel olarak, bu rekreasyon alanını ziyaret ettikten 
sonra kendimi enerji dolu hissettim." ifadesi olmuştur (İfade ort: 3,37). Bu ölçeğe ilişkin en düşük ortalamaya sahip ifade ise "Rekreasyon alanını ziyaret ettikten kısa bir süre sonra yaşam tatminimde artış oldu." ifadesi olarak tespit edilmiştir (İfade ort: 2,20).

Hipotez testleri yapılmadan önce tüm ölçeklerin ortalamaları alınarak hesaplamalar için hazır hale getirilmiştir. Bu aşamadan sonra çalışmaya katılan kişilerin parkları ziyaret sıklıkları ile deneyim kalitesi algılamaları arasında farklıık olup olmadığını incelemek üzere tek yönlü varyans analizi (ANOVA) testi uygulanmış ve sonuçları Tablo 5’te verilmiştir.

Tablo 5: Katılımcıların Parkları Ziyaret Sıklıkları ile Deneyim Kalitesi Algılamaları Arasındaki Farklılığın İncelenmesi

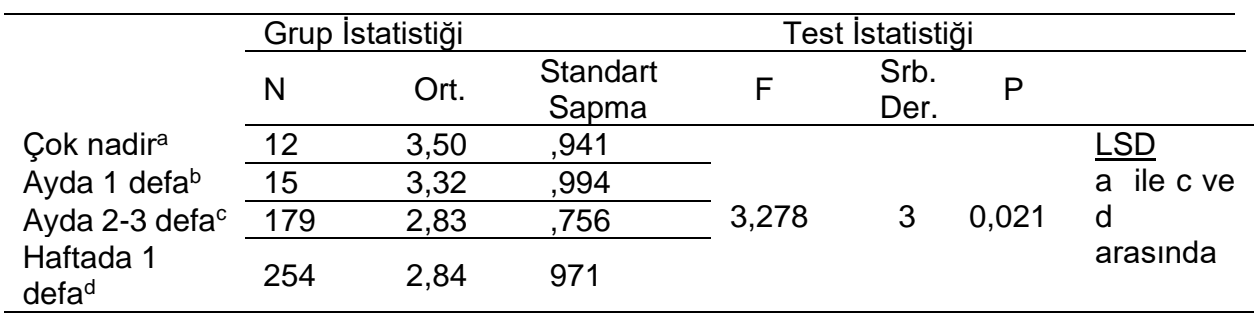

Tablo 5 'te yer alan sonuca göre 0,021 önem düzeyi ile $\mathrm{H}_{1}$ hipotezi kabul edilmiştir. Bir diğer ifade ile katılımcıların park ve bahçeleri ziyaret etme sıklıkları ile deneyim kalitesi algılamaları arasında istatistiksel açıdan anlamlı bir farklılık vardır $(p<0,05)$. Yapılan Post Hoc testleri ile farklıığın kaynağı incelendiğinde parkları çok nadir ziyaret edenler ile ayda 2-3 defa ile haftada 1 sıklıkta ziyaret edenler arasında deneyim kalitesi algılamaları arasında farklılık olduğu tespit edilmiştir. Bireylerin daha fazla park ziyareti gerçekleştirmesinin deneyim kalitelerini ve bunun devamında yaşam kalitesini olumlu etkileyeceği ifade edilebilir.

Katılımcıların algıladıkları memnuniyet düzeyinin park ve bahçeleri ziyaret sıklığına göre farklık gösterip göstermediğini tespit etmek amacıyla ANOVA testi uygulanmıştır.

\section{Tablo 6: Katılımcıların Parkları Ziyaret Sıklıkları ile Memnuniyet Algılamaları Arasındaki Farklılığın İncelenmesi}

\begin{tabular}{|c|c|c|c|c|c|c|c|}
\hline \multirow{6}{*}{$\begin{array}{l}\text { Çok nadira } \\
\text { Ayda } 1 \text { defa }^{b} \\
\text { Ayda } 2-3 \text { defa }^{c} \\
\text { Haftada } 1\end{array}$} & \multicolumn{2}{|c|}{ Grup İstatistiği } & \multicolumn{5}{|c|}{ Test İstatistiği } \\
\hline & $\mathrm{n}$ & Ort. & $\begin{array}{l}\text { Standart } \\
\text { Sapma }\end{array}$ & $\mathrm{F}$ & $\begin{array}{l}\text { Srb. } \\
\text { Der }\end{array}$ & $\mathrm{P}$ & \\
\hline & 12 & 3,18 & 1,570 & & & & LSD \\
\hline & 15 & 3,11 & ,981 & & & & $\bar{c}$ \\
\hline & 179 & 2,85 & 1,073 & 2,873 & 3 & 0,036 & diğerleri \\
\hline & 254 & 3,16 & 1,118 & & & & \\
\hline
\end{tabular}

Tablo 6'da görüldüğü üzere katılımcıların park ve bahçeleri ziyaret sıklıkları ile memnuniyet algılamaları arasında 0,036 önem düzeyi ile istatistiksel açıdan anlamlı bir farklılık vardır $(p<0,05)$. Bu sonuca göre $\mathrm{H}_{2}$ hipotezi kabul edilmiştir. Yani park ve bahçeleri ziyaret etme sıklığının artması memnuniyet üzerinde anlamlı bir etki oluşturmaktadır. Yapılan Post Hoc testleri ile farklılığın kaynağı incelendiğinde parkları ayda 2-3 defa ziyaret edenler ile diğer grupların memnuniyet düzeyleri arasında farklılık 
olduğu tespit edilmiştir. Elde edilen bulgulara göre bireylerin daha fazla park ziyareti gerçekleştirmesinin memnuniyeti etkilediği görülmektedir.

Katılımcıların yaşam kalitesi algılamalarının park ve bahçeleri ziyaret sıklığına göre farklık gösterip göstermediğini tespit etmek amacıyla tek yönlü varyans analizi (ANOVA) testi uygulanmıştır.

Tablo 7: Katıımcıların Parkları Ziyaret Sıklıkları ile Yaşam Kalitesi Algılamaları Arasındaki Farklıığın İncelenmesi

\begin{tabular}{|c|c|c|c|c|c|c|c|}
\hline & \multicolumn{2}{|c|}{ Grup İstatistiği } & \multicolumn{5}{|c|}{ Test İstatistiği } \\
\hline & $\mathrm{n}$ & Ort. & $\begin{array}{r}\text { Standart } \\
\text { Sapma } \\
\end{array}$ & $\mathrm{F}$ & $\begin{array}{l}\text { Srb. } \\
\text { Der }\end{array}$ & $\mathrm{P}$ & \\
\hline \multirow{4}{*}{$\begin{array}{l}\text { Çok nadira } \\
\text { Ayda } 1 \text { defa }^{\mathrm{b}} \\
\text { Ayda 2-3 defa } \\
\text { Haftada } 1 \\
\text { defa }^{\mathrm{d}}\end{array}$} & 12 & 3,14 & 1,184 & \multirow{4}{*}{8,879} & \multirow{4}{*}{3} & \multirow{4}{*}{0,000} & \multirow[t]{3}{*}{$\underline{\text { LSD }}$} \\
\hline & 15 & 3,07 & 1,223 & & & & \\
\hline & 179 & 2,42 & ,820 & & & & \\
\hline & 254 & 2,84 & ,971 & & & & \\
\hline
\end{tabular}

Tablo 7'de yer alan sonuçlara göre 0,000 önem düzeyi ile $\mathrm{H}_{3}$ hipotezi kabul edilmiştir. Bir diğer ifade ile katılımcıların park ve bahçeleri ziyaret etme sıklıkları ile yaşam kalitesi algılamaları arasında istatistiksel açıdan anlamlı bir farklılık vardır $(p<0,05)$. Yapılan Post Hoc testleri ile farklıı̆ı̆ın kaynağı incelendiğinde parkları ayda 23 defa ziyaret edenler ile daha farklı sıklıktaki sürelerde ziyaret edenler arasında yaşam kalitesi algılamaları arasında farklılık mevcuttur.

Araştırma değişkenlerinin birbirleri ile olan etkileşimini ortaya koymak amacıyla korelasyon testi uygulanmıştır. Korelasyon testine ilişkin bulgulara Tablo 8'de yer verilmiştir.

Tablo 8: Korelasyon (Pearson) Analizi Sonuçları

\begin{tabular}{llll}
\hline & DK & MEM & YK \\
\hline DK & 1 & & \\
\hline MEM &, $475^{\star *}$ & 1 & 1 \\
\hline YK &, $737^{* *}$ &, $714^{* *}$ &
\end{tabular}

** Korelasyon 0,01 düzeyinde anlamlıdır (çift yönlü).

Araştırma değişkenleri arasında ilişkinin yönünü gösteren korelasyon analizi sonuçlarının yer aldığı Tablo 8 incelendiğinde tüm değişkenler arasında pozitif yönlü bir ilişki olduğu, en yüksek ilişkinin deneyim kalitesi ve yaşam kalitesi değişkenleri arasında pozitif yönlü ve orta düzeyde gerçekleştiği görülmektedir.

Değişkenlere ait çoklu regreasyon analizi sonuçları Tablo 9'da gösterilmektedir.

Tablo 9: Yaşam Kalitesi ile Diğer Değişkenler Arasındaki Regresyon Analizi

\begin{tabular}{llcclcl}
\hline Model & $\begin{array}{l}\text { Standardize } \\
\text { Edilmemiş } \beta\end{array}$ & T & Sig. & $\begin{array}{l}\text { Çoklu } \\
\text { Bağlantı }\end{array}$ & Doğrusal & $\begin{array}{l}\text { Regresyon } \\
\text { Modeline Ait } \\
\text { Değerler }\end{array}$ \\
& & & Tolerans & VIF & \\
\hline DK &, 545 & 18,068 &, 000 &, 701 & 1,292 & $\begin{array}{l}\text { Adj. } \\
\mathrm{R}^{2}=, 713 \\
\mathrm{~F}: 57,668 \\
\mathrm{P}=, 000\end{array}$ \\
\hline MEM &, 401 & 16,522 &, 000 &, 774 & 1,315 & \\
\hline
\end{tabular}


Tablo 9'da yer alan bulguların yorumlanması için regresyon modelinde birden fazla bağımsız değişkenin bulunması halinde (Deneyim kalitesi, Memnuniyet) bu değişkenler arasında çoklu doğrusal bağlantı probleminin olup olmadığı incelenmelidir. $\mathrm{Bu}$ amaçla tolerans ve VIF değerleri önem göstermektedir. Çoklu doğrusal bağlantı problemi için ilk incelenmesi gereken değer tolerans değeridir. Hair ve diğ. (2003) bu değerin 0,10 üzerinde olması gerektiğini ifade etmektedir. Bir diğer önemli nokta olan VIF değerinin ise Allison'a (1999) göre 2,5 altında olması gerektiği, Hair ve diğ. (2010)'a göre ise 4 ve altında olması gerektiği ifade edilmiştir. Tablo 9 incelendiğinde tolerans ve VIF değerlerinin uygun olduğu ve çoklu doğrusal bağlantı probleminin olmadığı görülmektedir.

Katılımcıların yaşam kalitesi ile park ve bahçeleri kullanımları sonucu edindikleri deneyim kalitesi ve memnuniyet arasındaki ilişkiyi tespit edebilmek amacıyla kurulan regresyon modelinin pozitif yönde ve anlamlı olduğu görülmektedir ( $p=0,000)$. Bu sonuca göre $\mathrm{H}_{4}$ ve $\mathrm{H}_{5}$ kabul edilmiştir. Ayrıca yaşam kalitesinde yaşanan değişkenliğin \% 71 'inin deneyim kalitesi ve memnuniyet boyutları tarafından açıklanabilmektedir.

Tablo 10: Memnuniyet ile Diğer Değişkenler Arasındaki Regresyon Analizi

\begin{tabular}{lllllll}
\hline Model & $\begin{array}{l}\text { Standardize } \\
\text { Edilmemiş } \beta\end{array}$ & T & Sig. & $\begin{array}{l}\text { Çoklu Doğrusal } \\
\text { Bağlantı }\end{array}$ & $\begin{array}{l}\text { Regresyon } \\
\text { Modeline Ait } \\
\text { Değerler }\end{array}$ \\
\cline { 5 - 6 } & & & & Tolerans & VIF & \\
\hline DK &, 138 & 2,309 &, 021 &, 457 & 2,292 & $\begin{array}{l}\text { Adj. } \\
R^{2}=, 513 \\
F: 24,311\end{array}$ \\
&, 831 & 16,522 &, 000 &, 474 & 2,315 & \\
\hline YK & & & & & & \\
\hline
\end{tabular}

Tablo 10 incelendiğinde tolerans ve VIF değerlerinin uygun olduğu ve çoklu doğrusal bağlantı probleminin olmadığı görülmektedir. Katılımcıların memnuniyet düzeyleri ile park ve bahçeleri kullanımları sonucu edindikleri deneyim kalitesi ve yaşam kalitesi arasındaki ilişkiyi tespit edebilmek amacıyla kurulan regresyon modelinin pozitif yönde ve anlamlı olduğu görülmektedir $(\mathrm{p}=0,000)$. Bu sonuca göre $\mathrm{H}_{6}$ kabul edilmiştir. Ayrıca memnuniyet algısında yaşanan değişkenliğin \%51'inin deneyim kalitesi ve yaşam kalitesi boyutları tarafından açıklandığı görülmektedir.

\section{Sonuç ve Öneriler}

Köyden kente göç sonucu insan yaşamının çevresel olarak değişmesiyle birlikte şehirlerde oluşturulan park ve bahçelere insanların daha fazla intiyacı olduğu görülmektedir. Zira, rekreasyonel aktiviteleri gerçekleştirmenin insan sağlığı üzerinde önemli etkiler oluşturduğu düşünülmektedir. Park ve bahçelerin insanların memnuniyet ve yaşam kalitelerini nasıl etkilediğini ortaya koymaya çalışan bu çalışma birincil ve ikincil veriler kullanılarak hazırlanmıştır.

Çalışmanın çeşitli sonuç ve önerilerine aşağıdaki başlıklar altında yer verilmiştir.

\subsection{Uygulamaya Dönük Çıkarımlar}

Elde edilen sonuçlar doğrultusunda ziyaret sıklıklarının katılımcıların deneyim kalitesi, algıladıkları memnuniyet ve yaşam kalitesi üzerinde anlamlı etkileri olduğu görülmektedir. Park ve bahçeleri ayda 2-3 defa sıklıkta ziyaret edenlerin söz konusu değişkenleri algılama durumların daha yüksek olduğu gözlenmiştir. Bu doğrultuda park 
ve bahçeleri daha sık ziyaret etmenin insanların deneyim kalitelerini, memnuniyet algılarını ve yaşam kalitelerini arttıracağı ifade edilebilir. Bu anlamda yerel yönetimlerin ve şehir planlamacıların daha fazla ve ulaşılabilir park ve bahçe alanları oluşturmaları önerilmektedir.

Deneyim kalitesinin yaşam kalitesi üzerinde $\% 54,5$ düzeyinde olumlu etkisi olduğu tespit edilmiştir. Halkın yaşam kalitesinin artması psikolojik, sosyal ve ekonomik anlamda önemli kabul edilmektedir. Özellikle yoğun çalışma temposu sonrası stres atılabilmesi, ekran ve telefon bağımlıı̆ğının tetiklediği ve bugün halk sağlığı anlamında önemli bir sorun olarak kabul edilen obeziteye karşı etkin bir çözüm yöntemi olarak rekreasyon alanlarının arttırıması ve çeşitlendirilmesi önerilmektedir.

Yerel halkın deneyim kalitesindeki artışın memnuniyet üzerinde de bir etkisi olduğu tespit edilmiştir. Bu anlamda yerel halkın park ve bahçeleri kullanırken deneyim kalitelerini arttırmak memnuniyetlerini \%13 düzeyinde olumlu yönde etkilemektedir. Yerel yönetimlerin ve şehir planlamacılarının halkın deneyim kalitesini artırmak amacıyla park çeşitliliğini arttırması, konumlarının ve kullanış amaçlarının çeşitli bilimsel yöntemlerle belirlenerek projelendirilmesi önerilmektedir.

Millet bahçesi rekreasyon alanından elde edilen memnuniyetin halkın yaşam kalitesi üzerinde olumlu etkileri olduğu da görülmektedir. Bu sebeple memnuniyeti arttırmanın halkın yaşam kalitesindeki artışa önemli derecede etki edeceği söylenebilir. Özellikle "Millet Bahçeleri" kavramının oluşmasıyla birlikte elde edilen sonuçların planlama, projelendirme, uygulama ve işletme anlamında önemli fikirler vereceği ve katkı sağlayacağı düşünülmektedir.

\subsection{Akademik Öneriler}

Bu araştırmanın önemli teorik katkılarından biri Türkiye'deki park ve bahçelerin deneyim kalitesi algılarını ölçen sınırlı sayıda araştırma olması sebebiyle literatürdeki önemli bir boşluğu doldurmaktadır. Bunun yanında kullanılan ölçüm aracının deneyim kalitesi, memnuniyet ve yaşam kalitesi algısı arasındaki ilişkiyi açıklamak için yeterli olduğu görülmektedir. Özet olarak mevcut araştırma ölçeği farklı araştırma alanlarında söz konusu değişkenleri ölçmek adına kullanılabilir. Bu araştırma Kırıkkale ilinde bulunan yerel halkın rekreasyon alanlarında edindikleri (deneyim kalitesi, memnuniyet algısı ve yaşam kalitesi) değişkenlerin etkileri irdelenmiştir. Gelecek çalışmalarda "Millet Bahçeleri" ne yönelik farklı illerde yaşlı ve engelli bireylerin yaşam kalitesi ve memnuniyetlerine yönelik araştırmalar yürütülebilir. Bu araştırmanın seçildiği destinasyonun Ankara-Nevşehir destinasyonu yol güzergahında bulunması sebebiyle benzer özelliklere sahip Kırşehir ve Çankırı gibi diğer şehirlerde de uygulanması önerilmektedir. Ayrıca araştırma modeline algılanan değer, imaj ve davranışsal niyetler boyutlarının eklenmesi de söz konusu değişkenlerin daha kapsamlı etkilerini belirlemek açısından önem arz etmektedir. Regresyon analizleri veya yapısal eşitlik modellemesi aracılığıyla belirtilen değişkenlerin aracılık etkileri saptanarak destinasyona yönelik ulaşım, güvenlik, imaj algıları ve turizm potansiyeli ortaya konularak hem halkın hem de turistlerin davranışları hakkında tespitler öne sürülebilir.

\section{Kaynakça}

Allison, P. D. (1999). Multiple regression: A primer. Pine Forge Press.

Beard, J. ve Ragheb. M. (1980). "Measuring Leisure Satisfaction". Journal of Leisure Research 12 (1): 20-31. Akt: Lim, S.J. (2006). "The Influence of Service Quality on Consumer Satisfaction, Attitudinal Loyalty, Behavioral Future Intentions for 
Participation of Fitness Centers in South Korea: A Structural Equation Modeling Approach". Pro Quest Dissertations and Theses.

Büyüköztürk, Ş. (2006). Sosyal bilimler için veri analizi el kitabı-istatistik, araştırma deseni SPSS uygulamaları ve yorum, 6. Baskı, Ankara: Pegem Akademi Yayıncılık.

Diener, E. D., ve Eunkook Suh, M. (1997). Subjective well-being and age: An international analysis. Annual Review Of Gerontology And Geriatrics, 17, 304324.

Erkuş, A. (2013). Davranış bilimleri için bilimsel araştırma süreci [Scientific research process for the behavior sciences]. Ankara, Turkey: Seçkin Yayın Evi:(Gözden Geçirilmiş 4. Baskı).

Francken, D.A. ve vanRaaij, W.F. (1981). "Satisfaction with Leisure Time Activities". Journal of Leisure Research, 13(4), 337-352. Akt: Broughton, K.Beggs, B.A. (2007). "Leisure Satisfaction of Older Adults". Activities, Adaptation \& Aging, $31(1): 1-18$.

Göktaş, Z. (2007). Vergi Dairesi Başkanlığında Çalışan Personelin Boş Zamanlarını Değerlendirmesi Üzerine Bir Araştırma (Balıkesir Örneği). Spor Yönetimi ve Bilgi Teknolojileri Dergisi, 2(2).16-23.

Hair, J. F. Jr., Bush, R. P., ve Ortnau, D. J. (2003). Marketing research: within a changing Information environment, The McGraw-Hill/Irwin, Second Editon.

Hair, J. F., Black, WC, Babin, B. J., ve Anderson, RE (2010). Multivariate data analysis, 7. New Jersey: Pearson Prentice Hall.

Jin, N., Lee, S., ve Lee, H. (2015). The effect of experience quality on perceived value, satisfaction, image and behavioral intention of water park patrons: New versus repeat visitors. International Journal of Tourism Research, 17(1), 82-95.

Kim, H., Woo, E., ve Uysal, M. (2015). Tourism experience and quality of life among elderly tourists. Tourism management, 46, 465-476.

Kovacs, A., (2007). The Leisure Personality Relationships Between Personality, Leisure Satisfaction, and Life Satisfaction, PhD Thesis. School of Health, Physical Education and Recreation, Indiana University.

Lu, L., ve Hu, C., (2005).Personality, Leisure Experiences And Happiness, Journal of Happiness Studies, 6, 325-342.

Oliver, R. L. (1993). Cognitive, Affective, and Attribute Bases of the Satisfaction Response. Journal of Consumer Research, 20(3): 418-430.

Sato, M.,Yoshida, M., Wakayoshi, K., ve Shonk, D. (2017). Event satisfaction, leisure involvement and life satisfaction at a walking event: the mediating role of domain satisfaction. Leisure Studies, 36 (5), 605-617.

Spiers, A., ve Walker, G. (2009). The effects of Ethnicity and Leisure Satisfaction on Happiness, Peacefulness, and Quality of Life, Leisure Sciences, 31, 84-99.

Szalai, A. (1980). The meaning of comparative research on the quality of life. The quality of life, 7-21.

TUIK, (2019). Nüfus istatistikleri. https://biruni.tuik.gov.tr/bolgeselistatistik/degiskenlerUzerindenSorgula.do adresinden 08.10.2019 tarihinde ulaşılmıştır.

Van Kamp, I., Leidelmeijer, K., Marsman, G., and De Hollander, A. (2003). Urban environmental quality and human well-being: Towards a conceptual framework and demarcation of concepts; a literature study. Landscape and urban planning, 65(1-2), 5-18.

Veenhoven, R. (2007). Measures of gross national happiness (231-253). OECD World Economic.

Whoqol Group. (1995). The World Health Organization quality of life assessment (WHOQOL): position paper from the World Health Organization. Social science \& Medicine, 41(10), 1403-1409. 
Woo, E., Uysal, M., ve Sirgy, M. J. (2018). Tourism impact and stakeholders' quality of life. Journal of Hospitality \& Tourism Research, 42(2), 260-286.

Wu, H. C., Li, M. Y., ve Li, T. (2018). A study of experiential quality, experiential value, experiential satisfaction, theme park image, and revisit intention. Journal of Hospitality \& Tourism Research, 42(1), 26-73.

Yayla, Ö., ve Çetiner, H. (2019). Boş Zamanların Değerlendirilmesinde Etkili Olan Faktörlerin Boş Zaman Tatminine Etkisi. Turizm Akademik Dergisi, 6(1), 219-228.

Yıldız, B., Kılıç, N. S., ve Gürbüz, K. A. (2016). Balıkesir Kent Halkının Yaşadıkları Kentteki Rekreasyon Faaliyetlerine Katılımlerı ve Yerel Rekreasyon Imkanlarının Yeterlilik Düzeylerinin Belirlenmesi. Journal of Recreation and Tourism Research, 3(1), 10-23.

Yılmaz, Ş., Küçüktopuzlu, F. ve Çerez, H. (2006). The Recreational Activity Condition and Level of Satisfaction of Individuals in Antalya City, 9. Uluslararası Spor Bilimleri Kongresi, Muğla: Nobel Yayın Dağıtım.

Zikmund, W. G. (2003). Sample designs and sampling procedures. Business research methods, 7(2), 368-400.

T.C.

KIRIKKALE ÜNIVERSITESI

SOSYAL VE BESERI BILIMLER ARASTIRMALARI

ETIK KURULU TOPLANTISI

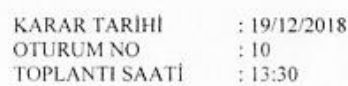

Sosyal ve Beşeri Bilimler Araștırmalan Ettik Kurulu, Kurul Başkanı Prof. Dr. Eyüp BAŞ başkanlığında gündemdeki maddeleri görüşmek üzere toplanarak aşađ̧ıdaki kararları almıştır.

GÜNDEM 2- Kırıkkale Oniversitesi Fatma SENSES Sosyal Bilimler Meslek Yaksek Okulu, Ögretim Görevlisi Dr. Ali SOLUNOĞLU tarafindan gönderilen proje başvunusunun göruạşulmesí.

Çalıșmanın Adı : Rekreasyon Deneyim Algılarının Yaşam Kalitesine Etkisi: Kırıkkale Örneği

Çalışmada Görevli Personeller :

\begin{tabular}{|c|l|l|l|l|l|}
\hline & Unvan Ad Soyad & Fakülte Bölüm & Telefon & e-mail & $\begin{array}{l}\text { Çalışmadaki } \\
\text { Gõrevi }\end{array}$ \\
\hline 1 & $\begin{array}{l}\text { Dr. Ali } \\
\text { SOLUNOGLU }\end{array}$ & $\begin{array}{l}\text { Kurkkale Üni. Fatma } \\
\text { Şenses Sosyal Bilimler } \\
\text { MYO }\end{array}$ & & & \\
\hline 2 & Dr. Ozgür YAYLA & $\begin{array}{l}\text { Ankara Hacı Bayram } \\
\text { Universitesi Turizm } \\
\text { Fakültesi }\end{array}$ & & & \\
\hline
\end{tabular}

KARAR 2 - Kırıkkale Üniversitesi Fatma SENSES Sosyal Bilimler Meslek Yüksek Okulu, Ōgetrim Görevlisi Kırıkale Orneģi" isimli proje incelen gönderilen "Rekreasyon Deneyim Algılarınn Yaşam Kalitesine Etkisi: Etik Kurulu Yonergesinde belirtilmiş olan Etik ilkelere 